\title{
Synergistic interaction between tetra-arsenic oxide and paclitaxel in human cancer cells in vitro
}

\author{
WON-HEUI CHUNG ${ }^{1}$, BONG HWAN SUNG ${ }^{2}$, SANG-SOO KIM ${ }^{1}$, HYANGSHUK RHIM ${ }^{1}$ and HYO-JEONG KUH ${ }^{1}$ \\ ${ }^{1}$ Department of Biomedical Sciences, College of Medicine, The Catholic University of Korea, \\ 505 Banpo-dong, Seocho-ku, Seoul 137-401, Korea; ${ }^{2}$ Department of Cancer Biology, \\ Vanderbilt University Medical Center, Nashville, TN 37232-6840, USA
}

Received January 9, 2009; Accepted March 13, 2009

DOI: 10.3892/ijo_00000298

\begin{abstract}
Similar to arsenic trioxide $\left(\mathrm{As}_{2} \mathrm{O}_{3}\right)$, tetra-arsenic oxide $\left(\mathrm{As}_{4} \mathrm{O}_{6}, \mathrm{TAO}\right)$ has shown anti-proliferative and apoptosis-inducing effects against human leukemic and solid tumor cells. In order to assess the increase in efficacy, we evaluated the combinatory interaction of TAO combined with paclitaxel, 5-FU or cisplatin and studied its mechanism of action in the cell lines of human gastric, cervix and head and neck tumors. Two agents were combined at equitoxic ratios based on the $\mathrm{IC}_{50}$ of each drug. Efficacy improvement was evaluated using a combination index and isobologram at $50 \%$ inhibition level. Apoptosis induction and expression of apoptosis-related proteins was determined and the effect on microtubule polymerization was monitored. TAO combined with paclitaxel showed synergistic interaction in all three of gastric, cervix and head and neck cancer cell lines. On the other hand, TAO when combined with 5-FU or cisplatin showed an antagonistic interaction in head and neck or cervix cancer cell lines, respectively. Simultaneous treatment with TAO with paclitaxel resulted in an increased percentage of apoptotic cells and a significant increase in PARP cleavage and caspase- 3 activation in the gastric and cervix cancer cells compared to TAO alone as well as the antagonistic groups (TAO with 5-FU or cisplatin). TAO suppressed the tubulin polymerization in the presence and absence of paclitaxel in a concentration-dependent manner, suggesting mitotic catastrophe as a potential mechanism of the synergism with paclitaxel. Overall, the present study suggests that TAO may have a greater potential as an anti-cancer agent against human gastric, cervix and head and neck tumors, in combination with paclitaxel. The synergistic interaction with paclitaxel may be associated with increased apoptosis via inhibition of paclitaxel-
\end{abstract}

Correspondence to: Dr Hyo-Jeong Kuh, Department of Biomedical Sciences, College of Medicine, The Catholic University of Korea, 505 Banpo-dong, Seocho-ku, Seoul 137-401, Korea

E-mail: hkuh@catholic.ac.kr

Key words: tetra-arsenic oxide, paclitaxel, combination index, apoptosis, tubulin polymerization induced tubulin polymerization. Further detailed studies of combinatory mechanisms and evaluation using in vivo models are warranted.

\section{Introduction}

Arsenic compounds have been used as therapeutic agents for rheumatism, syphilis and epilepsy since ancient times (1). Arsenic trioxide (ATO, Trisenox) has been used for the treatment of acute promyelocytic leukemia (APL) since 2000 and clinical trials for hepatocellular carcinoma and melanoma are now underway $(2,3)$. Arsenic sulfide also recently showed an anti-cancer effect against APL (4). Currently, other arsenic anti-cancer agents such as tetra-arsenic oxide $\left[\mathrm{As}_{4} \mathrm{O}_{6}\right.$, 2,4,6,8,9,10-Hexaoxa-1,3,5,7-tetraarsatricyclo(3.3.1.1 $\left.1^{3,7}\right)$ decane, TAO] and sodium meta arsenite are currently being developed (5-7).

Previous studies have shown that ATO induces apoptosis not only in human leukemic cells but also in human solid tumor cells (8-12). Activation of capase-3 following downregulation of bcl-2 and degradation of PML-RAR $\alpha$ protein was shown in the leukemic cancer cell lines $(13,14)$. In the solid tumor cells, the production of reactive oxygen species (ROS), loss of the mitochondrial membrane potential and caspase-3 activation were shown (15). ATO also showed a possibility of a synergistic interaction with sulindac, which is attributable to ROS-dependent regulation of p53 and survivin (16).

TAO has shown anti-proliferative and apoptosis-inducing effects and ROS production, leading to apoptosis is thought to be the major mechanism of the anti-cancer effect in leukemic cells (6). TAO and other arsenic compounds also showed potent activity against human solid tumors, such as prostate and cervix cancers $(7,17)$. Similar to ATO, efficacy of TAO may be improved via combination with other chemotherapeutic agents $(16,18,19)$. TAO also showed an inhibitory effect on tube formation of endothelial cells in vitro and an antiangiogenic effect in a rat model (20). These data testify to the potential of TAO against human solid tumors.

In the present study, we evaluated the effect of TAO in human gastric, cervix and head and neck tumor cells when in combination with paclitaxel, 5-FU or cisplatin, which are agents commonly used to treat these tumor types in the clinical setting. TAO showed the most synergistic interaction with 
paclitaxel, hence we measured the levels of apoptosis-related proteins and apoptosis induction to better understand the synergistic mechanisms. We further evaluated the effect of TAO on paclitaxel-induced microtubule polymerization and confirmed its reversal effect on polymerization.

\section{Materials and methods}

Cell culture. Human gastric (SNU-484, AGS and SNU-216), cervix (SiHa, CaSki and ME-180) and head and neck (FaDu) cancer cell lines were purchased from the Korean Cell Line Bank (Seoul, Korea). Two head and neck cancer cell lines (PCI-1 and AMC-HN-4) were kindly provided by Seoul National University (Seoul, Korea) and Asan Medical Center (Seoul, Korea), respectively. These cell lines were maintained using appropriate media such as RPMI-1640, EMEM and DMEM (Gibco BRL, Grand Island, NE) supplemented with $10 \%$ heat-inactivated FBS (Welgene Inc., Daegu, Korea), penicillin $100 \mathrm{U} / \mathrm{ml}$ (Sigma Chemical Co., St. Louis, MO) and streptomycin $100 \mu \mathrm{g} / \mathrm{ml}$ (Sigma Chemical Co.) in a humidified $5 \% \mathrm{CO}_{2}$ atmosphere at $37^{\circ} \mathrm{C}$.

Reagents. Tetra-arsenic oxide $\left(\mathrm{As}_{4} \mathrm{O}_{6}\right)$ was obtained from Chonjisan (Seoul, Korea). Cisplatin was kindly provided by the Drug Synthesis and Chemistry Branch of the Developmental Therapeutics Program at the National Cancer Institute (Bethesda, MD). Paclitaxel was donated by the Hanmi Research Center Co., Ltd. (Giheung, Korea). The other reagents were purchased from Sigma Chemical Co. unless otherwise noted. Tetra-arsenic oxide was dissolved in $1 \mathrm{~N}$ $\mathrm{NaOH}$, whereas the other agents were dissolved in dimethyl sulfoxide (DMSO) and both further diluted with PBS as needed.

Cytotoxicity assay. The sulforhodamine B (SRB) assay was performed, as previously described (21). Cells in the log phase of growth were harvested and plated on 96-well plates at a predetermined density (1000-3000 cells/well). After $24 \mathrm{~h}$ of incubation, the cells were exposed to drug-containing media for $72 \mathrm{~h}$. The cells were then fixed with $10 \%$ tri-chloroacetic acid (TCA) and stained with $0.4 \%$ SRB solution for $10 \mathrm{~min}$. After washing, the protein-bound dye was extracted with $10 \mathrm{mM}$ buffered Tris (Amresco, Solon, $\mathrm{OH}$ ) and the optical absorbance was measured.

Western blot analysis. After drug exposure, cells were harvested, washed with ice-cold PBS and lysed in lysis buffer supplemented with protease inhibitors. Protein concentrations were measured by Bradford assay. Lysate was separated on SDS-PAGE gels (12\% of acrylamide) and transferred onto polyvinylidene difluoride (PVDF) membranes (Bio-Rad, Richmond, CA). After blocking using $5 \%$ skimmed milk, the membranes were incubated with primary antibodies. The following primary antibodies were used at the dilution indicated in the manufacturer's manual. a) Anti-PARP antibody (BD Transduction Laboratories, Lexington, KY, b) anti-cleaved caspase-3 antibody (Cell Signaling Technology, Danvers, MA), c) anti-p53 antibody (Santa Cruz Biotechnology, Santa Cruz, CA), d) anti-Bax antibody (Santa Cruz Biotechnology), e) anti-ß-actin antibody
(Santa Cruz Biotechnology). After washing with TBST, membranes were incubated with horseradish peroxidaseconjugated secondary antibodies (Santa Cruz Biotechnology) and immunoblots were visualized by enhanced chemiluminescence (Amersham Bioscience, Piscataway, NJ) according to the manufacturer's protocol. The cytosolic fractions isolated from the cells were used for Western blot analysis of cytochrome-c as previously described $(22,23)$. Cytochrome-c protein was detected using anti-cytochrome-c antibody (Santa Cruz Biotechnology).

Apoptosis detection assay. Apoptosis was measured using an annexin V fluorescein isothiocyanate (FITC) apoptosis detection kit I (BD Pharmingen, San Diego, CA). After drug exposure, cells were washed twice with cold PBS and then resuspended in binding buffer and stained with annexin $\mathrm{V}$ FITC and propidium iodide (PI) for $15 \mathrm{~min}$ at $25^{\circ} \mathrm{C}$ in the dark. Samples were then analyzed using a FACSCalibur and data were acquired using Cell Quest software (Becton-Dickinson, San Jose, CA).

Tubulin polymerization assay and staining. Mouse embryonic fibroblasts were generously provided by S.K. Hanks (Department of Cell and Developmental Biology, Vanderbilt University School of Medicine, Nashville, TN). For tubulin staining, mouse embryonic fibroblast cells were incubated for $24 \mathrm{~h}$ on a coverslip. After drug exposure for 24,48 and $72 \mathrm{~h}$, cells were washed with PBS and stained with anti-ß-tubulin antibody (Sigma Chemical Co.) at $4^{\circ} \mathrm{C}$ for $1 \mathrm{~h}$. After the incubation, slides were washed with PBS and stained with Alexa-488-conjugated anti-mouse IgG antibody (Invitrogen, Carlsbad, CA). Slides were washed with PBS and then examined using the Leica Confocal TCS 4D Laser Scanning Microscope (Leica, Nussuloch, Germany).

For the tubulin polymerization assay, the tubulin polymerization assay kit was used according to the manufacturer's protocol (Cytoskeleton, Inc., Denver, Co.). Drug solution diluted with general tubulin buffer (80 mM PIPES, $2 \mathrm{mM}$ $\mathrm{MgCl}_{2}, 0.5 \mathrm{mM}$ EGTA) was loaded into the 96-well plate and then, incubated at $37^{\circ} \mathrm{C}$ for $2 \mathrm{~min}$. Tubulin was defrosted and diluted with ice-cold tubulin polymerization buffer (general tubulin buffer containing 15\% glycerol and $1 \mathrm{mM}$ of GTP). The diluted protein was then immediately loaded into the pre- warmed 96-well plate using a multi-channel pipette and the polymerization reaction was initiated. Tubulin polymerization was monitored spectrophotometrically by the change in absorbance at $340 \mathrm{~nm}$. The observance was measured at $1 \mathrm{~min}$ intervals for $30 \mathrm{~min}$ at $37^{\circ} \mathrm{C}$.

Data analysis. Changes in cell growth (\% of cell survival) were calculated using (Eq. 1). The median effect model was used to analyse the cell survival data (Eq. 2).

$$
\begin{aligned}
& \% \text { Cell survival }=\frac{\text { mean absorbance of treated cells }}{\text { mean absorbance of control cells }} \\
& \% \text { Cell survival }=(100-R) \times\left(1-\frac{[D]^{m}}{K_{d}^{m}+[D]^{m}}\right)+R
\end{aligned}
$$

where (D) is the drug concentration, $K_{d}$ is the concentration of drug that produces a $50 \%$ reduction of the maximum 
Table I. Anti-proliferative activity of tetra-arsenic oxide in comparison with paclitaxel, 5-FU and cisplatin in human gastric, cervix and head and neck cancer cell lines.

\begin{tabular}{lccccc}
\hline & Cell line & Paclitaxel $(\mathrm{nM})$ & $5-\mathrm{FU}(\mu \mathrm{M})$ & Cisplatin $(\mu \mathrm{M})$ & TAO $(\mu \mathrm{M})^{\mathrm{a}}$ \\
\hline Gastric cancer & SNU-484 & $4.86 \pm 1.01$ & $15.5 \pm 2.05$ & $64.9 \pm 7.02$ & $0.94 \pm 0.03$ \\
& AGS & $8.07 \pm 2.52$ & $3.44 \pm 0.31$ & $14.7 \pm 0.95$ & $0.68 \pm 0.12$ \\
& SNU-216 & $5.83 \pm 0.50$ & $7.54 \pm 1.89$ & $6.70 \pm 2.01$ & $0.76 \pm 0.40$ \\
Average \pm SD & & $6.25 \pm 1.64$ & $8.82 \pm 6.13$ & $28.7 \pm 31.5$ & $0.79 \pm 0.13$ \\
Cervix cancer & SiHa & $364 \pm 310$ & $153 \pm 54.7$ & $22.6 \pm 1.35$ & $2.20 \pm 1.11$ \\
& CaSki & $12.1 \pm 3.30$ & $3.60 \pm 0.60$ & $15.9 \pm 1.18$ & $0.47 \pm 0.004$ \\
Average \pm SD & ME-180 & $4.25 \pm 1.12$ & $2.10 \pm 0.49$ & $2.55 \pm 1.17$ & $1.52 \pm 0.20$ \\
Head and neck cancer & & $126 \pm 205$ & $52.9 \pm 86.6$ & $13.6 \pm 10.2$ & $1.39 \pm 0.87$ \\
& PCI-1 & $11.7 \pm 2.47$ & $3.29 \pm 1.31$ & $4.49 \pm 0.77$ & $1.13 \pm 0.18$ \\
Average \pm SD & AC-HN-4 & $1.38 \pm 0.19$ & $7.58 \pm 1.10$ & $4.38 \pm 1.63$ & $0.74 \pm 0.12$ \\
Total average \pm SD & FaDu & $3.58 \pm 0.77$ & $8.75 \pm 0.61$ & $14.3 \pm 1.54$ & $1.03 \pm 0.21$ \\
\hline
\end{tabular}

The median effect model (Eq. 2) was fitted to the dose-response data. The inhibitory concentration $\left(\mathrm{IC}_{50}\right)$ was calculated as a value to the absolute $50 \%$ reduction in survival. ${ }^{\mathrm{T}} \mathrm{TAO}$, tetra-arsenic oxide.

inhibition rate (Emax), $\mathrm{m}$ is a Hill-type coefficient and $\mathrm{R}$ is the residual unaffected (resistance) fraction $(\mathrm{R}=100-$ Emax $)$. $\mathrm{IC}_{50}$ was defined as the drug concentration required to reduce viability to $50 \%$ of the control (i.e., $\mathrm{K}_{\mathrm{d}}=\mathrm{IC}_{50}$ when $\mathrm{R}=0$ ).

The combination index (CI) was calculated using the following equation (Eq. 3),

$\mathrm{CI}=\frac{(\mathrm{D})_{\mathrm{A}}}{\left(\mathrm{D}_{50}\right)_{\mathrm{A}}}+\frac{(\mathrm{D})_{\mathrm{B}}}{\left(\mathrm{D}_{50}\right)_{\mathrm{B}}}+\alpha \frac{(\mathrm{D})_{\mathrm{A}}(\mathrm{D})_{\mathrm{B}}}{\left(\mathrm{D}_{50}\right)\left(\mathrm{D}_{50}\right)_{\mathrm{B}}}$

where $\left(D_{50}\right)_{A}$ and $\left(D_{50}\right)_{B}$ are the concentrations of drug $A$ or $B$ alone giving an $50 \%$ reduction in cell viability compared to a control. (D) $)_{\mathrm{A}}$ and $(\mathrm{D})_{\mathrm{B}}$ are the concentration of drug $\mathrm{A}$ and $\mathrm{B}$ in combination producing an $50 \%$ reduction in cell viability compared to a control. $\alpha$ is 0 when $\mathrm{A}$ and $\mathrm{B}$ are mutually exclusive or 1 when they are mutually non-exclusive (24). CI $<0.8$ was considered synergistic, 0.8-1.2 was considered additive and $>1.2$ was considered an antagonistic interaction.

Isobologram analysis was performed using Steel and Peckham's model, as previously described $(25,26)$. An isobologram consists of three iso-effect lines, which were constructed based on the dose-response curves of each agent. Mode I line was created under the assumption that the action mechanism between two agents was mutually exclusive. On the contrary, Mode II line was created based on non-exclusive interaction. When the coordinate of the combination dose expressed as a fraction of $\mathrm{IC}_{50}$ located below or above to the additivity envelope (area surrounded by mode I and mode II lines), a synergistic or antagonistic interaction was assigned for the combination, respectively.

Analysis of variance (ANOVA) followed by Bonferroni post-hoc test was performed using SPSS $^{\circledR}$ for Windows, version 8.0. A $\mathrm{p}<0.05$ was considered statistically significant.

\section{Results}

Anti-proliferative activity of TAO. The anti-proliferative activity of TAO was determined after $72 \mathrm{~h}$ of continuous exposure and compared to that of 5-FU, paclitaxel and cisplatin. Paclitaxel showed $\mathrm{IC}_{50}$ 's in the $\mathrm{nM}$ range, whereas the other drugs including TAO in the $\mu \mathrm{M}$ range (Table $\mathrm{I}$ ). In gastric cancer cells, TAO showed a 10 - to 30 -fold lower $\mathrm{IC}_{50}$ compared to $5-\mathrm{FU}$ or cisplatin based on the average $\mathrm{IC}_{50}$ in three cell lines tested i.e., 0.79 vs. 8.82 or $28.7 \mu \mathrm{M}$, respectively. The lower $\mathrm{IC}_{50}$ of $\mathrm{TAO}$ also was shown in cervix cancer cell lines, with a 10 - to 40 -fold difference, but to a lesser extent than the 10-fold difference in head and neck cancer cell lines. These results indicate the higher potency of $\mathrm{TAO}$ in gastric and cervical cancers.

The average $\mathrm{IC}_{50}$ of TAO was $0.79,1.39$ and $0.96 \mu \mathrm{M}$ against gastric, cervix and head and neck cancer cell lines, respectively (Table I), indicating a relative resistance in cervix cancer cell lines compared to the gastric and head and neck. Nonetheless, TAO showed a similar $\mathrm{IC}_{50}$ among the tumor types tested, i.e., 0.79 to $1.39 \mu \mathrm{M}$, whereas the other agents showed a wide range of $\mathrm{IC}_{50}$ 's (Table I). These data suggest similar activity of TAO against these gastric, cervix and head and neck tumors in comparison with other agents.

Synergy evaluation of TAO-containing combination. The synergistic interactions of TAO with 5-FU, paclitaxel or cisplatin were examined in cell lines of human gastric, cervix and head and neck tumors. Each agent was combined at an equitoxic ratio based on $\mathrm{IC}_{50}$. TAO with paclitaxel showed a synergistic interaction with CIs of $0.55,0.55$ and 0.73 in gastric, cervix and head and neck cancer cell lines, respectively (Table II). The synergistic interaction was obtained in all 
Table II. Combination index (CI) of tetra-arsenic oxide when combined with paclitaxel, 5-FU and cisplatin in human gastric, cervix and head and neck cancer cell lines.

\begin{tabular}{lcccc}
\hline & Cell line & $\mathrm{TAO}^{\mathrm{a}}+\mathrm{PTX}^{\mathrm{b}}$ & $\mathrm{TAO}^{\mathrm{a}}+5-\mathrm{FU}^{2}$ & $\mathrm{TAO}^{\mathrm{a}}+\mathrm{Cis}^{\mathrm{c}}$ \\
\hline Gastric cancer & SNU-484 & $0.21 \pm 0.02$ & $1.32 \pm 0.05$ & $0.31 \pm 0.002$ \\
& $\mathrm{AGS}$ & $0.73 \pm 0.03$ & $1.12 \pm 0.05$ & $0.56 \pm 0.04$ \\
& SNU-216 & $0.73 \pm 0.18$ & $0.40 \pm 0.03$ & $2.47 \pm 0.26$ \\
Average \pm SD & & $0.55 \pm 0.30$ & $0.94 \pm 0.48$ & $1.11 \pm 1.18$ \\
Cervix cancer & SiHa & $0.54 \pm 0.13$ & $0.38 \pm 0.15$ & $1.66 \pm 0.20$ \\
& CaSki & $0.50 \pm 0.06$ & $0.68 \pm 0.05$ & $0.92 \pm 0.04$ \\
Average \pm SD & ME-180 & $0.62 \pm 0.03$ & $1.15 \pm 0.09$ & $0.88 \pm 0.06$ \\
Head and neck cancer & & $0.55 \pm 0.06$ & $0.73 \pm 0.38$ & $1.15 \pm 0.43$ \\
& PCI-1 & $0.18 \pm 0.01$ & $1.57 \pm 0.14$ & $0.22 \pm 0.04$ \\
Average \pm SD & AC-HN-4 & $0.88 \pm 0.03$ & $1.15 \pm 0.02$ & $0.95 \pm 0.05$ \\
Total average \pm SD & FaDu & $1.14 \pm 0.10$ & $1.11 \pm 0.33$ & $1.29 \pm 0.02$ \\
\hline
\end{tabular}

CI was calculated at the $50 \%$ growth inhibition levels with $\alpha=0$ assuming two agents are mutually exclusive (Eq. 3 ). Drug treatments were given simultaneously for $72 \mathrm{~h}$ at equitoxic ratios. ${ }^{\mathrm{a}} \mathrm{TAO}$, tetra-arsenic oxide; ${ }^{\mathrm{b}} \mathrm{PTX}$, paclitaxel and ${ }^{\mathrm{c}} \mathrm{Cis}$, cisplatin.

SNU-484
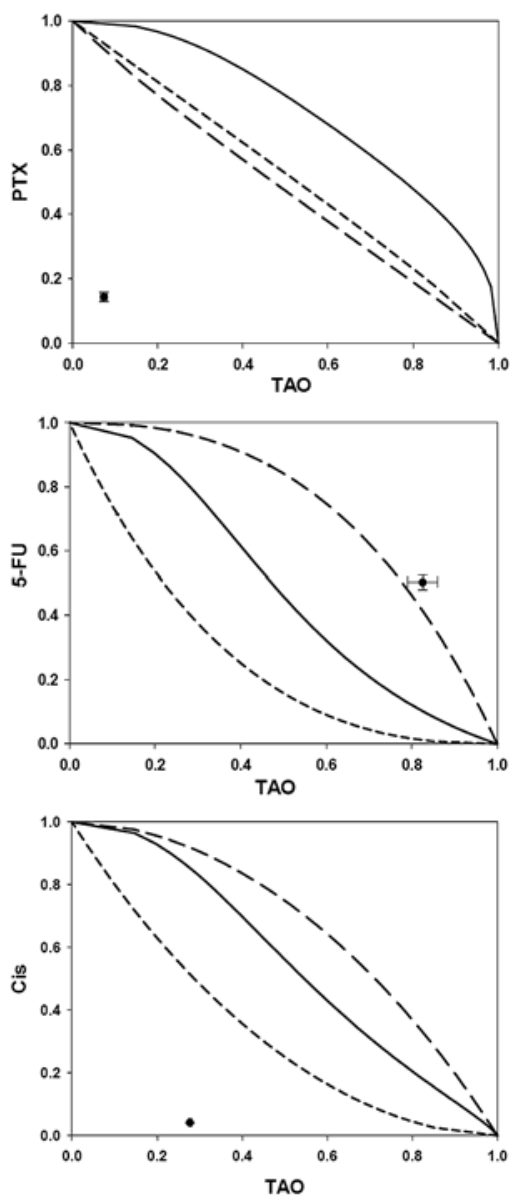

AGS
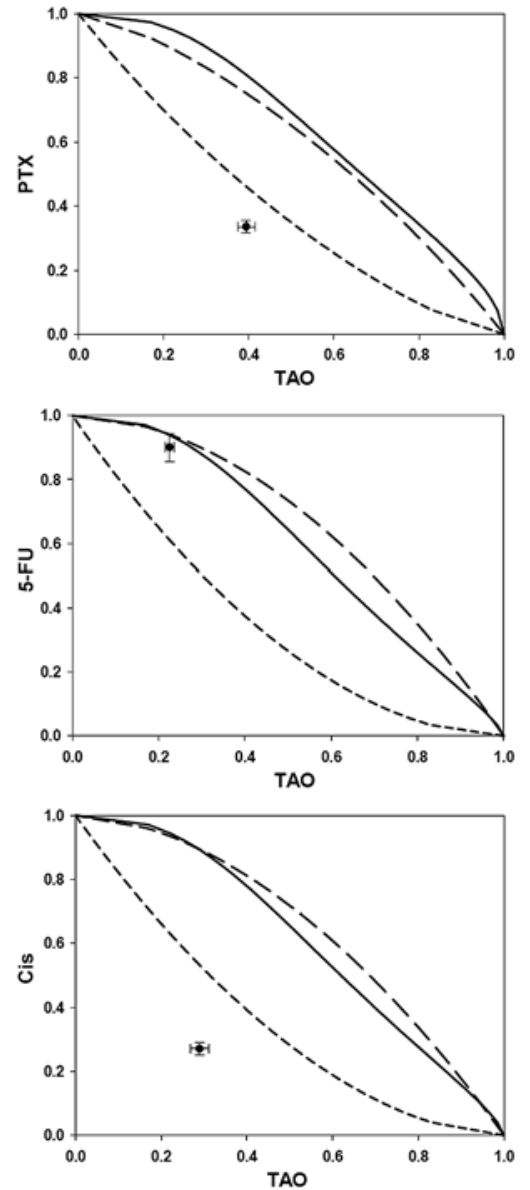

SNU-216
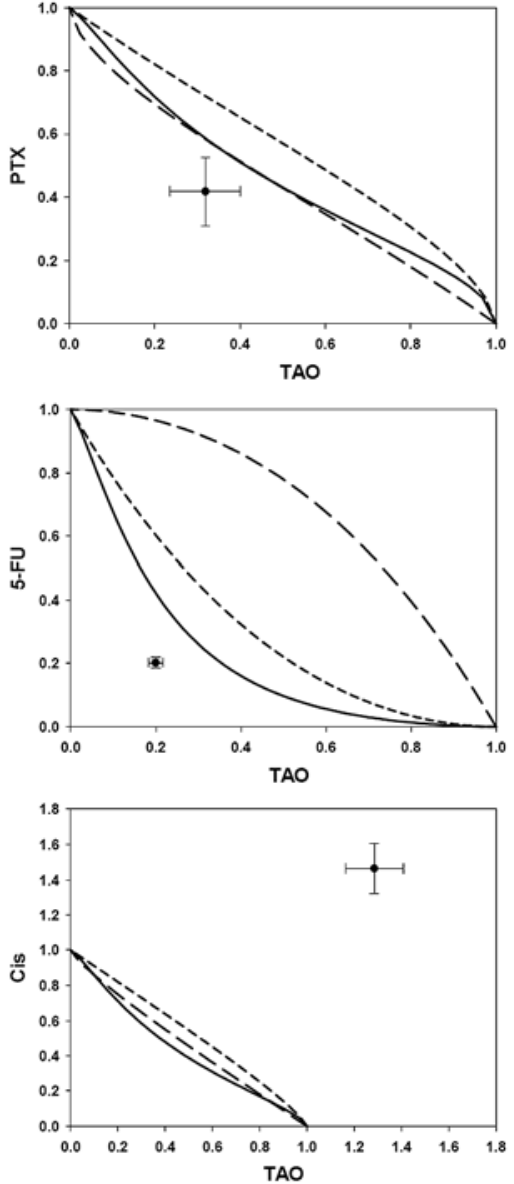

Figure 1. Combined interaction between tetra-arsenic oxide (TAO) and other anti-cancer agents (paclitaxel, 5-FU and cisplatin) in 3 human gastric cancer cell lines. PTX, paclitaxel; Cis, cisplatin; - , MODE I; --, MODE IIa; ---, MODE IIb. 
SiHa
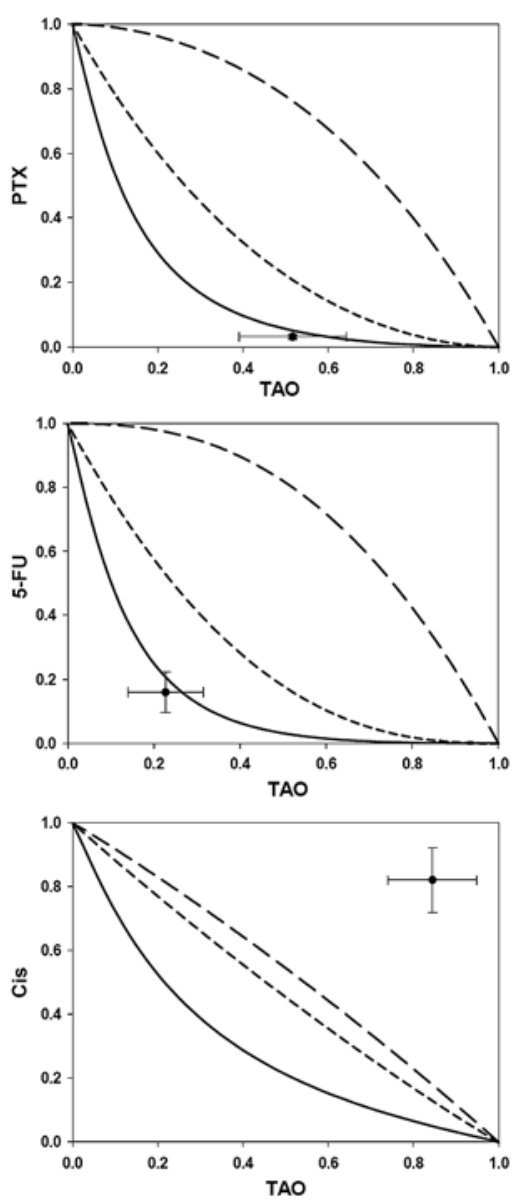

Caski
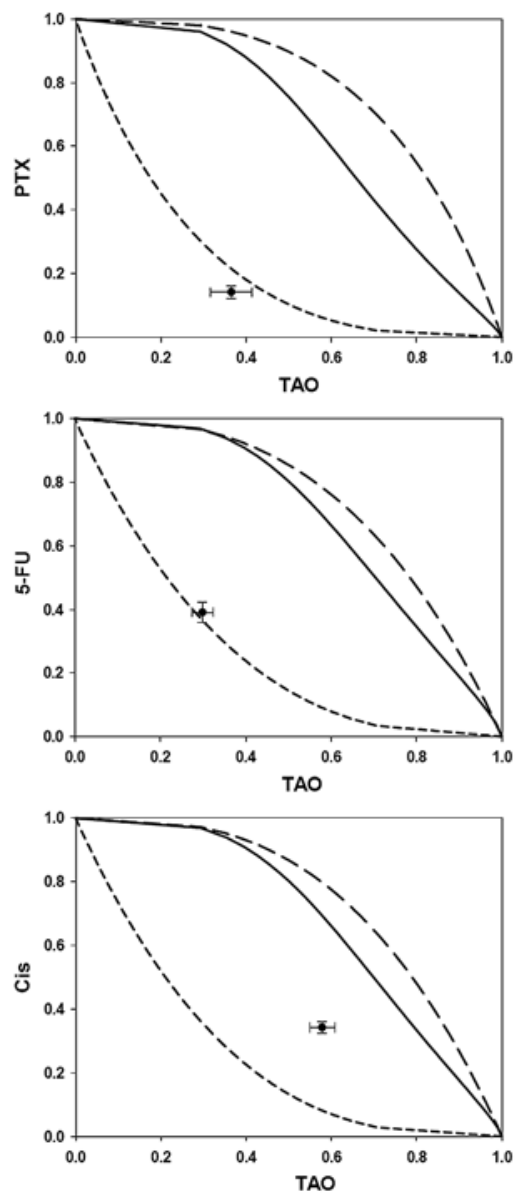

ME-180
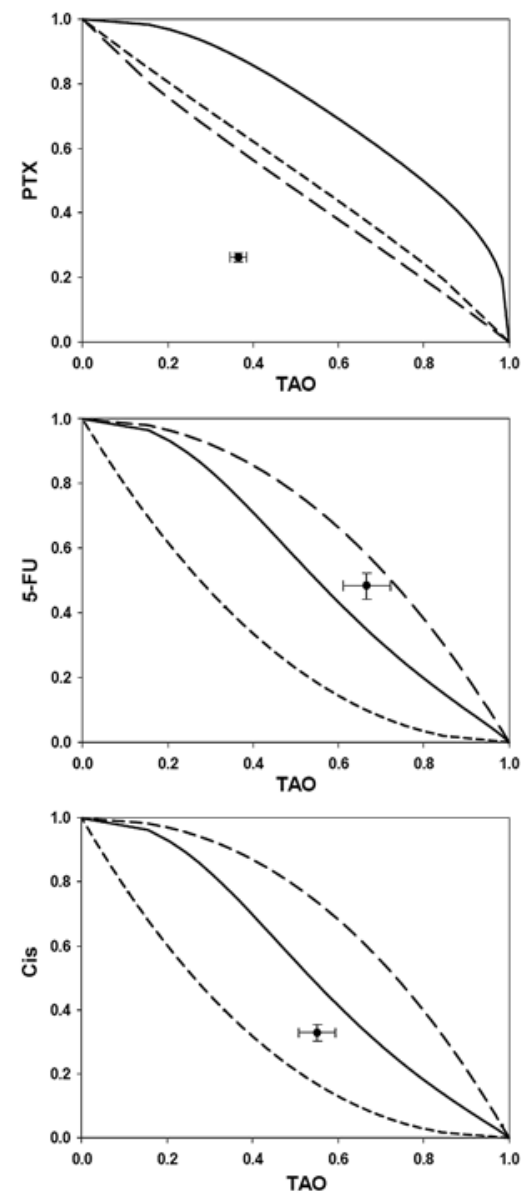

Figure 2. Combined interaction between tetra-arsenic oxide (TAO) and other anti-cancer agents (paclitaxel, 5-FU and cisplatin) in 3 human cervix cancer cell lines. PTX, paclitaxel; Cis, cisplatin; -, MODE I; --, MODE IIa; ---, MODE IIb.

three cell lines of gastric and cervix and in one out of three cell lines of head and neck cancer as shown with CI index (Table II) and isobologram analysis (Figs. 1-3). TAO combined with 5-FU showed an additive or synergistic interaction with CIs of 0.94 and 0.73 in gastric and cervix cancer cell lines, respectively. However, an additive to antagonistic interaction was seen in head and neck cell lines (Table II). The same results were obtained using isobologram analysis (Figs. 1-3). TAO with cisplatin showed an additive interaction in cervix and head and neck cancer cell lines (Table II). In gastric cancer cell lines, TAO with cisplatin showed a synergistic to antagonistic interaction depending on the cell line (Table II). Overall, in gastric cancer cell lines and in head and neck cancer cell lines, TAO only when combined with paclitaxel showed synergistic interaction. In cervix cancer cell lines, TAO combined with paclitaxel as well as 5-FU showed synergistic interaction.

Apoptosis induction of TAO alone or in combination. In order to evaluate the association of apoptotic pathway in synergistic interaction, the changes in expression level of apoptosis-related proteins in SNU-484 (gastric), SiHa (cervix) and PCI-1 (head and neck) cells were determined. In SNU-484 cells, single treatment with TAO showed PARP cleavage and caspase-3 activation $(17 \mathrm{kDa})$. The TAO combined with paclitaxel (synergistic group) also showed PARP cleavage, whereas the TAO with 5-FU (antagonistic group) showed decreased PARP cleavage resulting from no active caspase-3 level. In the case of p53, single treatment of TAO showed no significant change and combination with 5-FU (antagonistic group) resulted in increased expression compared to combination with paclitaxel (synergistic group) (P-value <0.05), (Fig. 4B). No significant change in Bax level was noted in any of the treatment groups (Fig. 4B).

In SiHa cells, the TAO alone group showed weak PARP cleavage along with a subtle increase in active caspase-3 (19 kDa) (Fig. 5). The TAO with paclitaxel (synergistic group) showed prominent PARP cleavage and caspase-3 activation $(19 \mathrm{kDa})$ compared to combination with cisplatin (antagonistic group) (P-value <0.05) (Fig. 5). In the case of p53, Bax and cytochrome-c, no significant change was noted either between the negative control and TAO single treatment or TAO with paclitaxel (synergistic group) and TAO with cisplatin (antagonistic group) (Fig. 5B).

In PCI-1 cells, the TAO alone group showed clear PARP cleavage and an increase in active caspase-3 (19 kDa) expression compared to the untreated group (Fig. 6A). Expression of cleaved PARP, activated caspase-3 (19 kDa), 
PCI-1
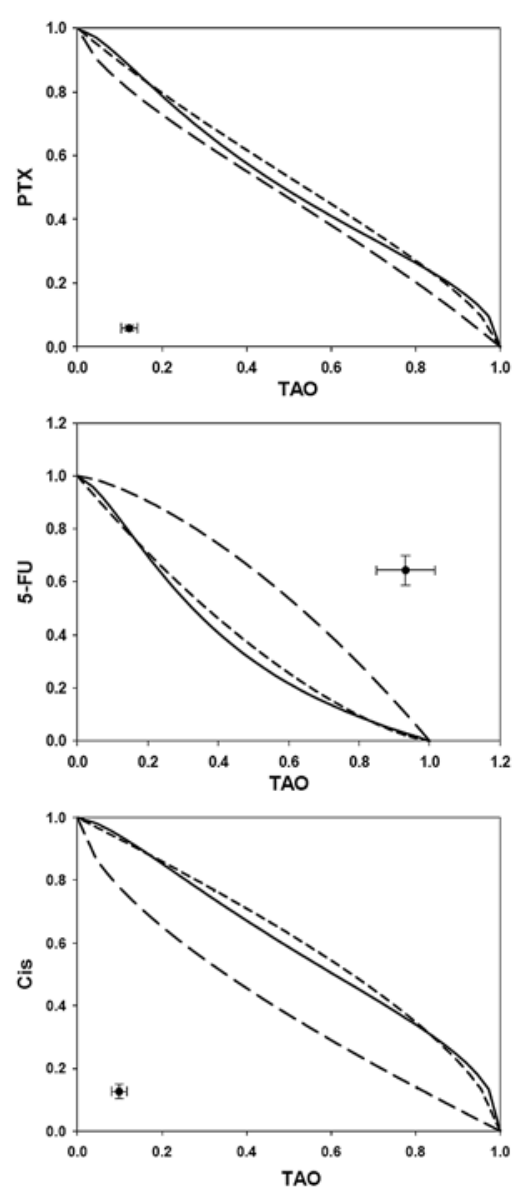

AMC-HN-4
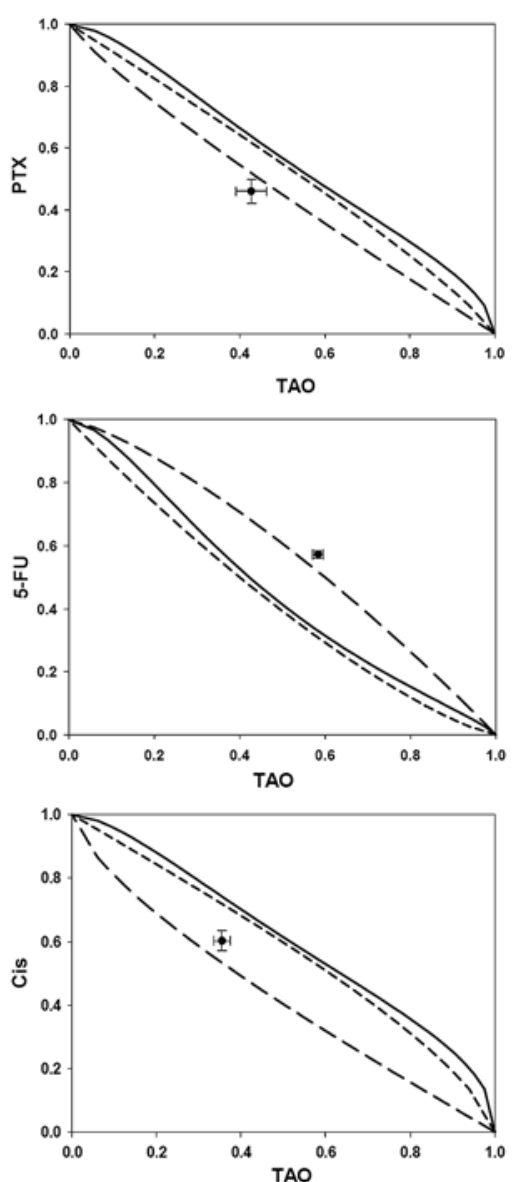

FaDu
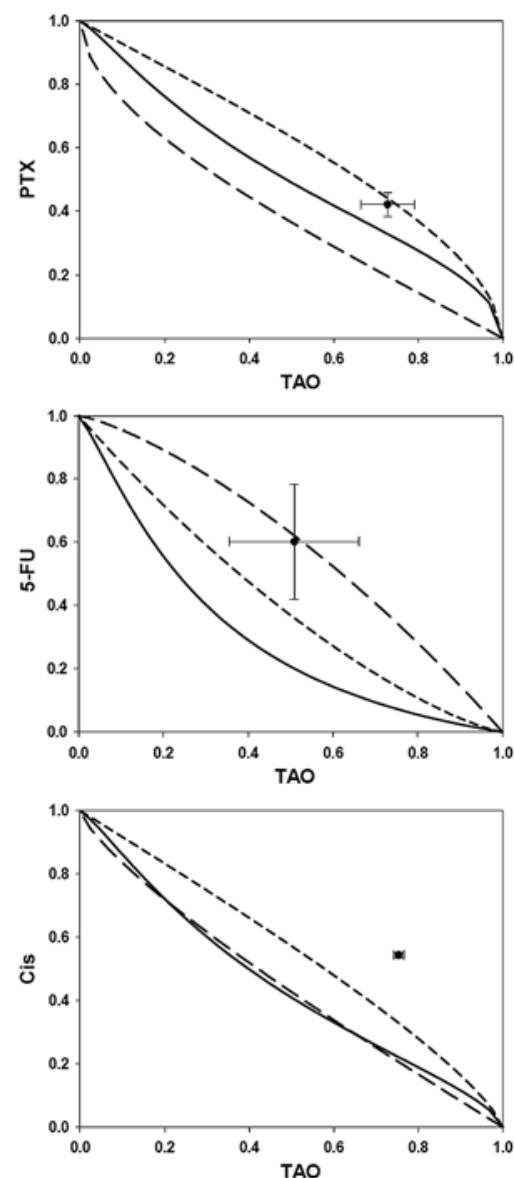

Figure 3. Combined interaction between tetra-arsenic oxide (TAO) and other anti-cancer agents (paclitaxel, 5-FU and cisplatin) in 3 human head and neck cancer cell lines. PTX, paclitaxel; Cis, cisplatin; - , MODE I; --, MODE IIa; ---, MODE IIb.

A

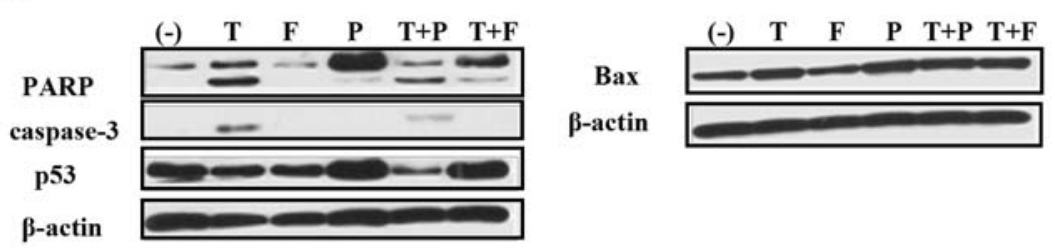

B
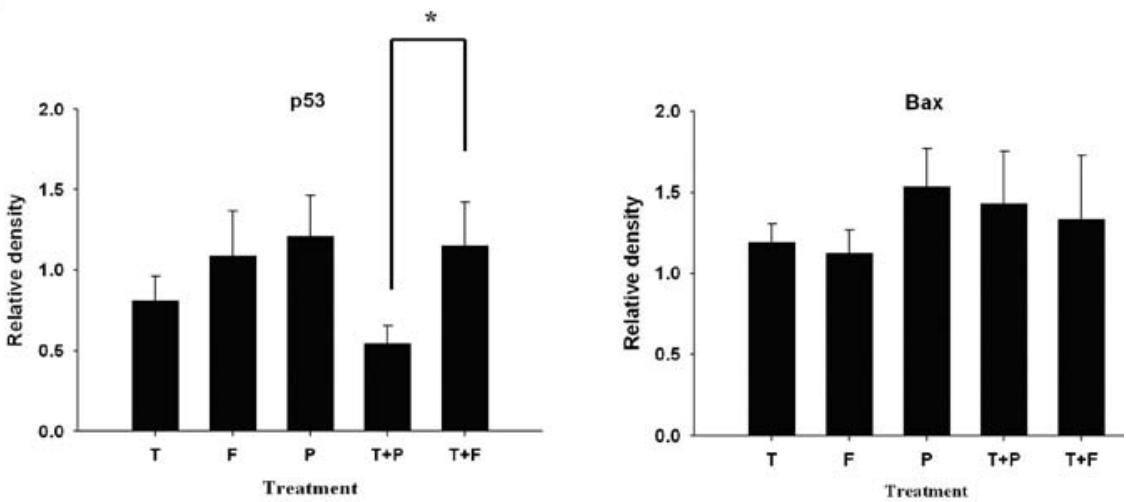

Figure 4. SNU-484 cells were exposed to tetra-arsenic oxide $(1 \mu \mathrm{M}), 5$-FU $(10 \mu \mathrm{M})$ and paclitaxel $(0.01 \mu \mathrm{M})$ either alone or in combination for $12 \mathrm{~h}$. PARP, active caspase-3, p53 and Bax were detected by Western blot analysis. (A) Representative gel image. (B) Densitometry analysis of p53 and Bax levels. (-), Untreated control; T, tetra-arsenic oxide; F, 5-FU and P, paclitaxel. Densitometry data were expressed as a relative density to a negative control. ${ }^{*} \mathrm{P}<0.05$. 
A

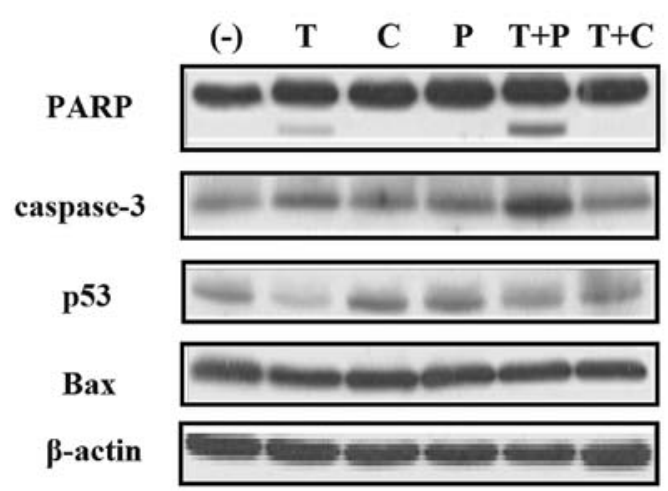

cytochrome-c

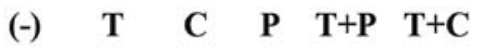

$\beta$-actin
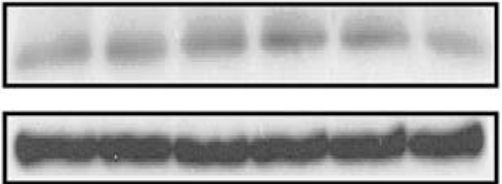

B
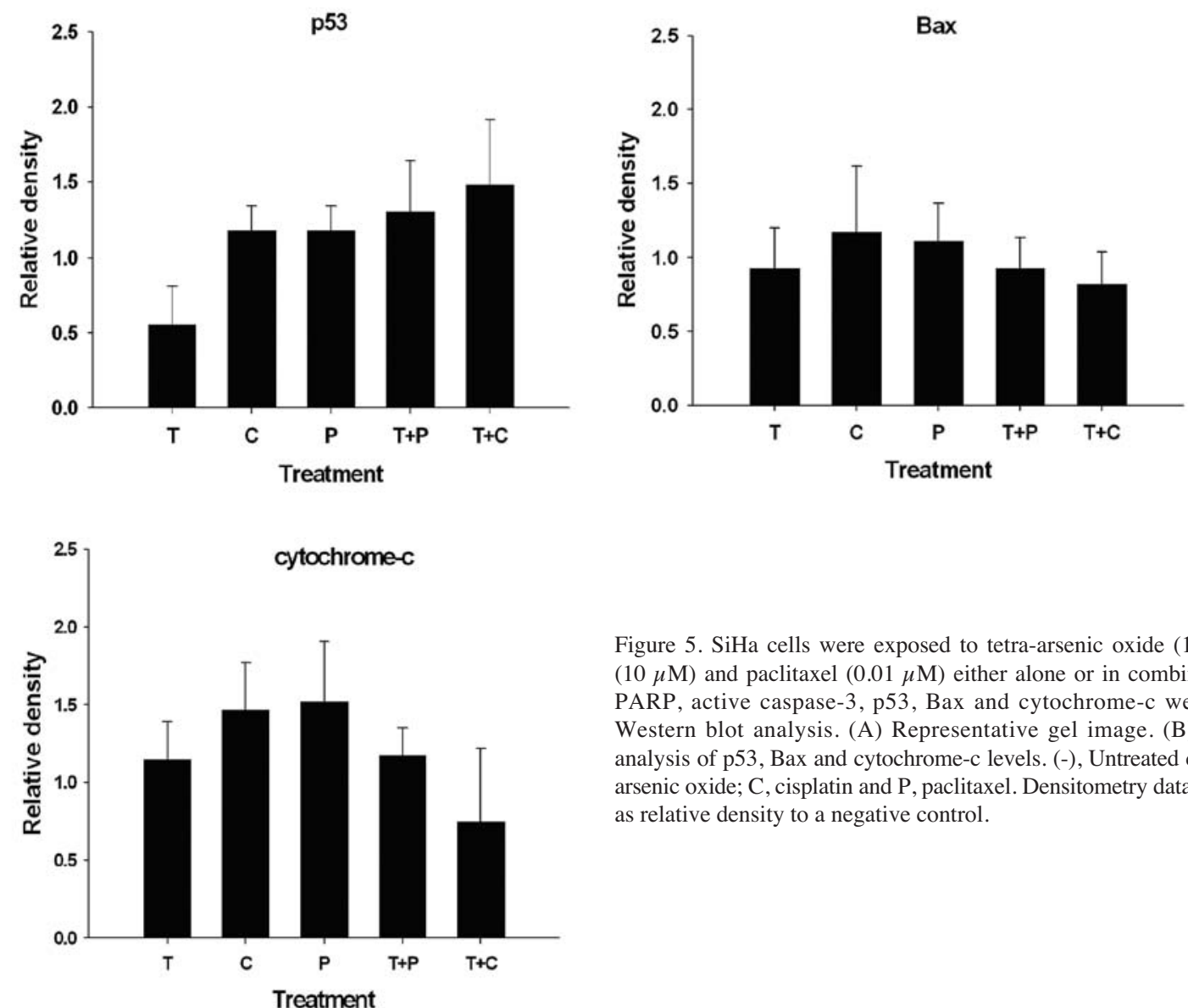

Figure 5. SiHa cells were exposed to tetra-arsenic oxide $(1 \mu \mathrm{M})$, cisplatin $(10 \mu \mathrm{M})$ and paclitaxel $(0.01 \mu \mathrm{M})$ either alone or in combination for $24 \mathrm{~h}$. PARP, active caspase-3, p53, Bax and cytochrome-c were detected by Western blot analysis. (A) Representative gel image. (B) Densitometry analysis of p53, Bax and cytochrome-c levels. (-), Untreated control; T, tetraarsenic oxide; C, cisplatin and P, paclitaxel. Densitometry data were expressed as relative density to a negative control.

p53 and Bax were similar among the drug-treated groups including the TAO with paclitaxel (synergistic group) and 5-FU (antagonistic group) (Fig. 6).

In order to investigate the contribution of apoptosis to the synergistic effect, the percentage of apoptotic cells was measured and compared between the synergistic and antagonistic groups in SNU-484 human gastric cancer cells. $\mathrm{TAO}$ at $10 \mu \mathrm{M}$ induced apoptosis in $61.1 \%$ of cells and combination with $0.1 \mu \mathrm{M}$ of paclitaxel (synergistic group), increased apoptotic cells to $74.7 \%$ (Fig. 7), indicating an increase in $13.6 \%(\mathrm{P}<0.01)$. On the contrary, when TAO was

combined with $100 \mu \mathrm{M}$ of 5-FU (antagonistic group), the percentage of apoptotic cells decreased by $7.0 \%$ from TAO single treatment $(\mathrm{P}<0.05)$. Although paclitaxel $(0.1 \mu \mathrm{M})$ or 5-FU $(100 \mu \mathrm{M})$ showed similar levels of apoptotic induction when given alone $(37.3,39.6 \%$, respectively), significant differences in the percentage of apoptotic cells were observed when combined with TAO. i.e., 74.7 vs. $54.1 \%$ (Fig. 7).

Effect of TAO on tubulin polymerization. In order to investigate the mechanism of synergistic interaction between 
A

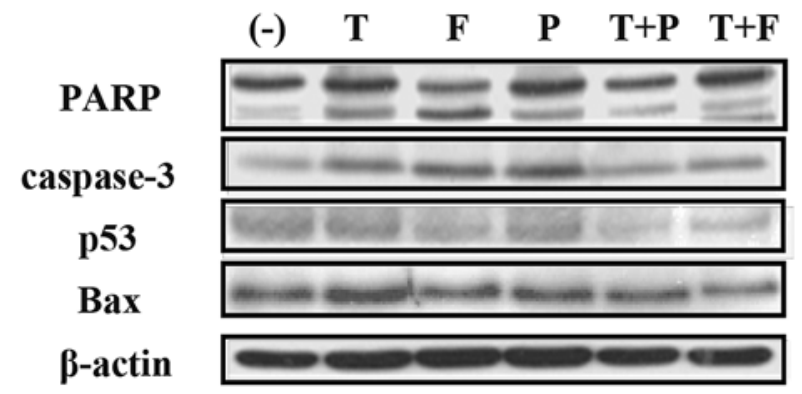

B

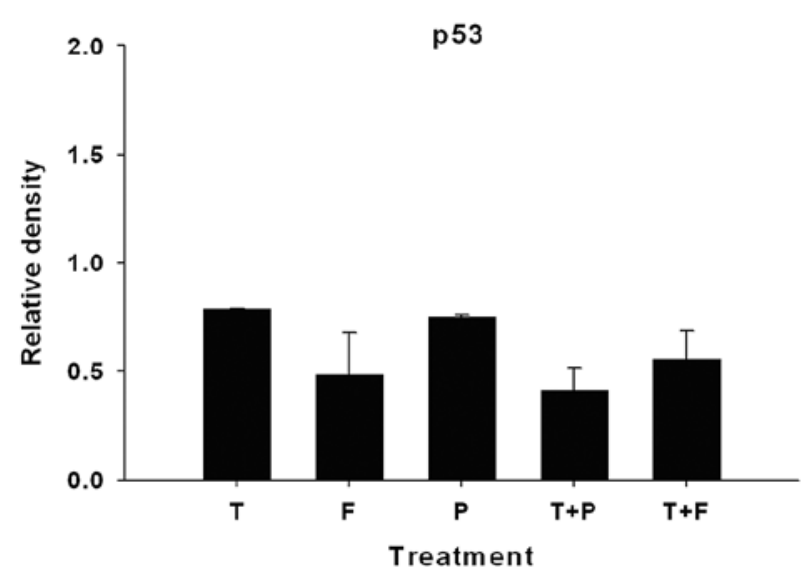

TAO and paclitaxel, we evaluated the effect of TAO either alone or in combination with paclitaxel using a tubulin staining assay as well as an in vitro microtubule polymerization assay. TAO treatment inhibited microtubule polymerization resulting in a decrease in the microtubule density compared to the untreated control (Fig. 8A). The microtubule polymerization assay also showed polymerization inhibition in a concentrationdependent manner, resulting in complete blockage of polymerization at $1000 \mu \mathrm{M}$ of TAO (Fig. 8B). When combined with paclitaxel, TAO also inhibited paclitaxel-induced polymerization and showed a $50 \%$ decrease of maximum polymerization at $1000 \mu \mathrm{M}$ of TAO (Fig. 8C). These data indicated that TAO antagonized the effect of paclitaxel on microtubule polymerization and this may be associated with the synergistic interaction between these two drugs.

\section{Discussion}

The present study evaluated the interaction between TAO and other cytotoxic agents in human gastric (3 cell lines), cervix ( 3 cell lines) and head and neck (3 cell lines) cancer cells. The $\mathrm{IC}_{50}$ of $\mathrm{TAO}$ in these cell lines ranged from 0.47 to $2.20 \mu \mathrm{M}$ and the average value $(1.04 \mu \mathrm{M})$ was higher than that seen in $\mathrm{U} 937$ human leukemic cells $(0.20 \mu \mathrm{M})$ as reported elsewhere (Table I) (6). This indicates that leukemic cells may be more sensitive to TAO compared to solid cancer cells. Among the solid tumor types tested in the present study, gastric cancer cell lines showed the highest sensitivity with
Figure 6. PCI-1 cells were exposed to tetra-arsenic oxide $(1 \mu \mathrm{M}), 5$-FU $(10 \mu \mathrm{M})$ and paclitaxel $(0.01 \mu \mathrm{M})$ either alone or in combination for $12 \mathrm{~h}$. PARP, active caspase-3, p53 and Bax were detected by Western blot analysis. (A) Representative gel image. (B) Densitometry analysis of active caspase-3, p53 and Bax. (-), Untreated control; T, tetra-arsenic oxide; F, 5-FU and $\mathrm{P}$, paclitaxel. Results are expressed as a relative density to a negative control.

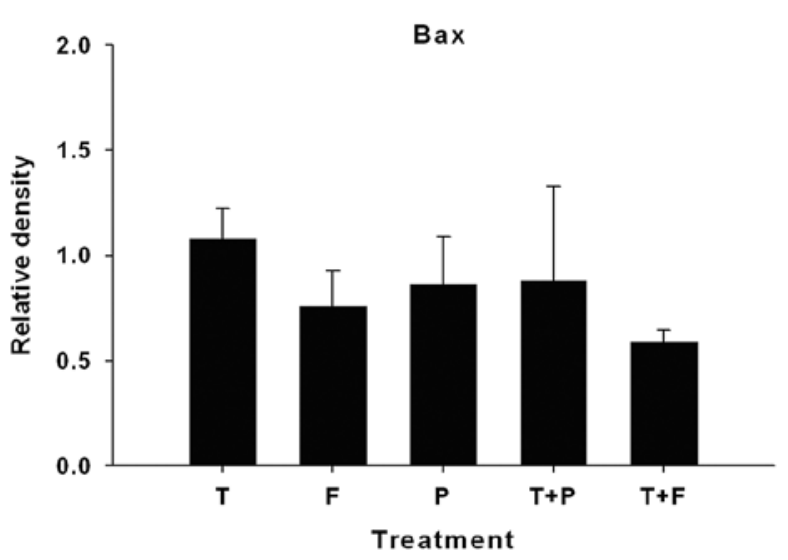

sub $\mu \mathrm{M} \mathrm{IC}_{50}$ values in all three cell lines (Table I). When compared to 5-FU and cisplatin, TAO showed greater cytotoxicity with less difference among tumor types, suggesting the potent anti-tumor activity of TAO against gastric, cervix and head and neck cancers. When doseresponse curves were analyzed by using the median effect model (Eq. 2), the m (Hill-type coefficient) of TAO (1.99) was significantly higher compared to 5-FU (1.03) in gastric, cervix and head and neck cancer cells $(\mathrm{P}<0.05)$, indicating that TAO may require a smaller increase in dose intensity to induce greater anti-proliferative effect than 5-FU. On the other hand, cisplatin showed a similar m value (1.60) to TAO. Considering the fact that TAO showed minimal toxicity in phase I trial, these pharmacodynamic characteristics may add an additional benefit to TAO-based regimen in terms of potency and adverse reactions.

ROS production, cytochrome-c release and caspase- 3 activation have been reported to be the mechanism of action for TAO-induced apoptosis (6). ATO also has been reported to induce loss of mitochondrial trans-membrane potential through ROS generation. This mitochondrial damage results in caspase- 3 activation via up-regulation of p53 and sequential activation of $\operatorname{Bax}(8,10,15)$. We selected one cell line that showed a significant synergy between TAO and paclitaxel from each tumor type, then, determined changes in the level of caspase-3 activation and PARP cleavage along with p53, Bax and cytochrome-c release. No significant difference was observed in cells treated for different duration of time (data 


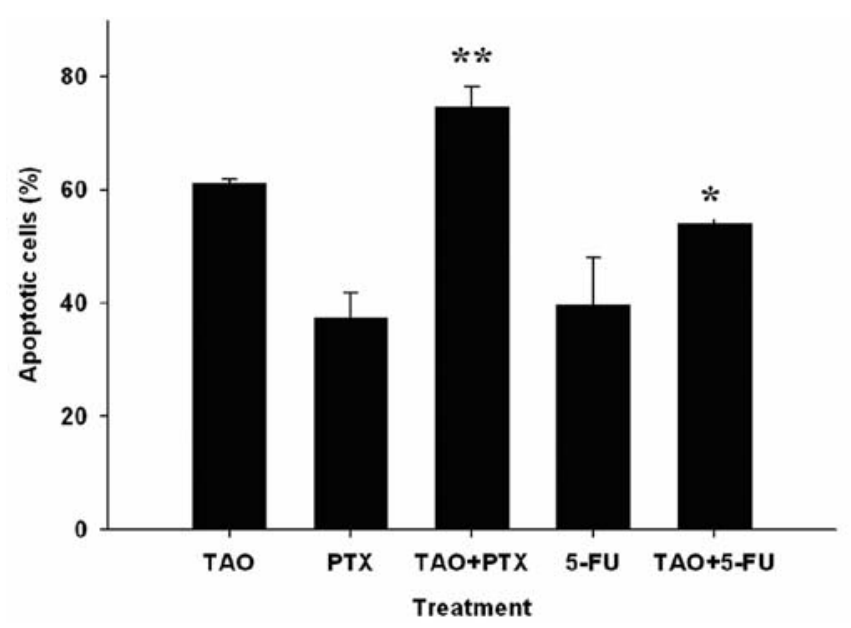

Figure 7. The percentage of apoptotic cells were determined in SNU-484 cells exposed to tetra-arsenic oxide $(10 \mu \mathrm{M})$, paclitaxel $(0.1 \mu \mathrm{M})$ and 5-FU $(100 \mu \mathrm{M})$ either alone or in combination for $24 \mathrm{~h}$. TAO, tetra-arsenicoxide and PTX, paclitaxel. ${ }^{* *} \mathrm{P}<0.01,{ }^{*} \mathrm{P}<0.05$ when compared to TAO only. not shown), hence, the data obtained after 12 or $24 \mathrm{~h}$ exposure are shown in Figs. 4, 5 and 6 (27). Caspase-3 activation was confirmed along with PARP cleavage in TAO-treated gastric, cervix and head and neck cells in our study (Figs. 4, 5 and 6). However, a significant increase was not observed either in p53 or Bax or cytochrome-c in any of the cell lines tested (Figs. 4B, $5 \mathrm{~B}$ and $6 \mathrm{~B})$. These results suggest a different mechanism of TAO-induced apoptosis from ATO, e.g., a p53-independent pathway to apoptosis as reported for ATO in the neuroblastoma cell line (28).

Paclitaxel showed a stronger synergistic interaction with TAO than 5-FU or cisplatin in all three types of tumor cell lines tested in our study (Table II). In particular, the most synergistic interaction between paclitaxel and TAO was shown in SNU-484 gastric cancer cell line with a CI value of 0.21 . This value indicates that when combined, only $11 \%$ of single treatment dose of TAO and paclitaxel can induce the same $50 \%$ inhibition in cell proliferation. Synergistic interaction may depend on the dose ratio of drugs to be combined, nonetheless,

A

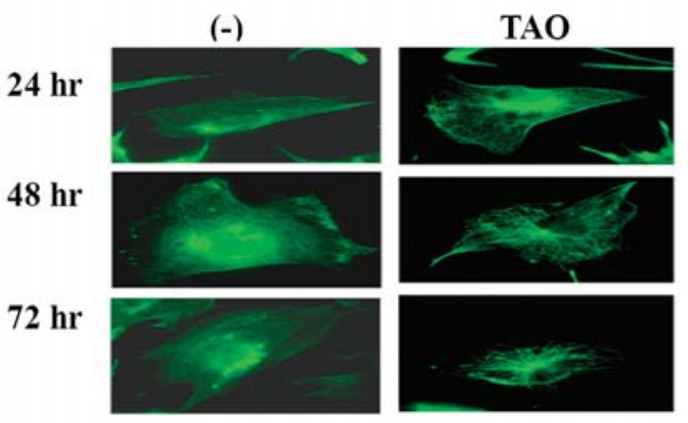

B

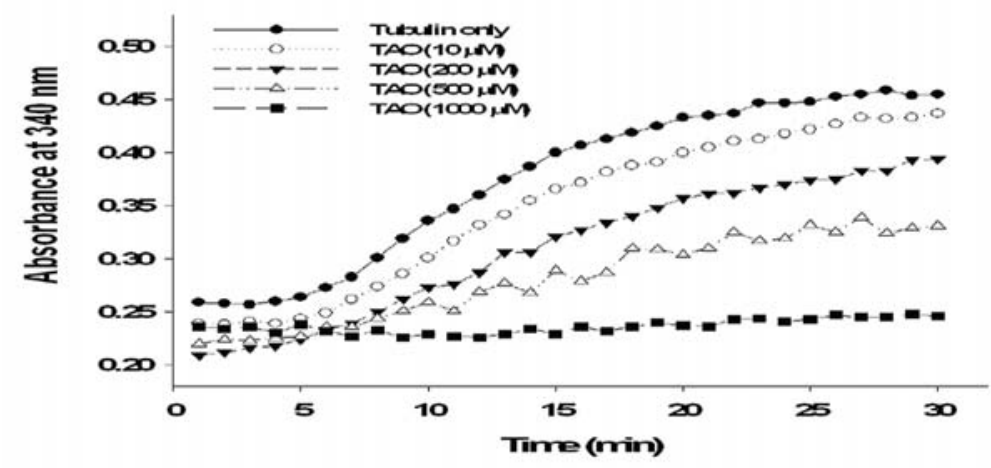

C

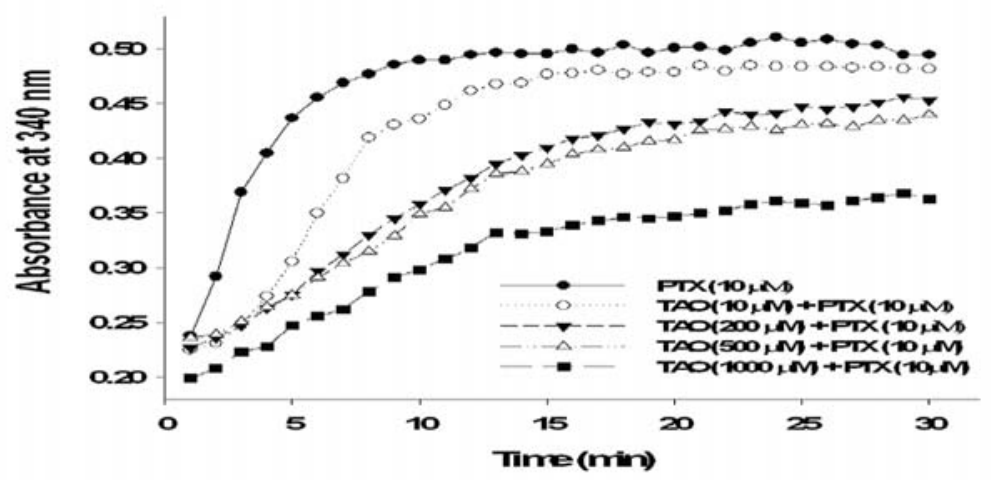

Figure 8. Effect of TAO on microtubule polymerization in the presence or absence of paclitaxel. (A) Effect of TAO ( $2 \mu \mathrm{M})$ on the organization of microtubule in mouse embryonic fibroblast cells. (-), Untreated control. (B) TAO inhibited tubulin polymerization in a concentration-dependent manner (10, 200, 500 and $1000 \mu \mathrm{M})$. (C) Paclitaxel (10 $\mu \mathrm{M})$-induced tubulin polymerization was inhibited by TAO in a concentration-dependent manner (10, 200,500 and $1000 \mu \mathrm{M})$. 
the use of equitoxic ratios are most frequently reported in the literature (16). We also used the equitoxic ratios in order to measure the interaction when both drugs can affect the cell viability to a similar extent.

The synergistic interaction between TAO and paclitaxel was confirmed by an increase in the percentage of apoptotic cells as determined through analysis of annexin (+) cells and it seemed to be related to caspase-dependent apoptotic induction as supported by an increased level of active caspase- 3 when compared to antagonistic combination of TAO with 5-FU in SNU-484 cells $(\mathrm{CI}=1.32)$ (Figs. 4 and 7). Combination interaction with 5-FU was dependent on cell lines, i.e., TAO with 5-FU showed synergy in SNU-216 cells with a CI of 0.4 (Table II), which was confirmed through increased apoptotic cell death $(60.3 \%)$ compared against the TAO alone group $(43.7 \%)$ or TAO with cisplatin (antagonistic group, $\mathrm{CI}=2.47$, $33.0 \%$ ), (data not shown).

The increase in the percentage of apoptotic cells for synergistic combinations, nonetheless, appeared to be less than expected from CI index or from respective single treatment. We speculate that induction of apoptosis may not be the sole mechanism for the synergism. In recent studies, autophage (type II programmed cell death), instead of apoptosis was observed in malignant glioma cells as well as in breast cancer cells treated with ATO $(2 \mu \mathrm{M})$ and paclitaxel analogs (AGS115 and EFDAC), respectively $(29,30)$. These data suggest that autophagic cell death may be another potential mechanism of synergistic interaction between TAO and paclitaxel. We can not rule out the possibility that the degree of apoptosis is not represented by the percentage of apoptotic cells seen at a single time point.

ATO has shown synergistic interaction with sulindac and phytosphingosine via ROS-dependent regulation of p53 and Bax in both leukemia and lung cancer cells. These signals induced activation of caspases and PARP, in sequence $(16,19)$. In our study, increases in PARP cleavage and caspase-3 activation were also seen in the synergistic combination in gastric and cervix cancer cells (Figs. 4 and 5). However, no significant difference was noticed in the level of Bax or p53. The level of p53 expression was even higher in the antagonistic combination (TAO + 5-FU) than in the synergistic group (TAO + paclitaxel) in SNU-484 gastric cancer cells (Fig. 4B). This suggests a p53-independent mechanism for the synergistic interaction of TAO-based combination, which warrants further investigation.

In order to further investigate the mechanism of synergism between TAO and paclitaxel, we measured the effect of TAO on microtubule polymerization in the presence and absence of paclitaxel (Fig. 8). TAO suppressed tubulin polymerization in both conditions. The combination of paclitaxel with oxaliplatin also has shown synergistic interaction in colon and gastric cancer cells $(31,32)$. The mechanism underlying this synergism was attributed to mitotic catastrophe associated with suppression of survivin expression (31). Since platinum compounds have shown an inhibitory activity on tubulin polymerization (33), synergism between paclitaxel and TAO may also act via a mitotic catastrophe mechanism. However, in contrast to our results, ATO has previously shown an antagonistic interaction with paclitaxel and it has been attributed to inhibition of tubulin polymerization by ATO (34).
Taken together, it can be speculated that the inhibition of paclitaxel-induced tubulin polymerization may result in either synergism or antagonism depending on the cellular context, which warrants further investigation.

Overall, our study demonstrated the pharmacodynamic interaction and its mechanism when TAO is given in combination with other conventional chemotherapeutic agents. Paclitaxel showed a synergistic interaction with TAO in gastric, cervix and head and neck cancer cell lines. We showed that this synergistic interaction may be related to caspase- 3 and PARP-dependent, but p53-independent induction of apoptosis. Furthermore, TAO suppressed paclitaxel-induced microtubule polymerization to a similar extent as ATO. These data support the chemotherapeutic potential of TAO, especially in combination with paclitaxel against human gastric, cervix and head and neck cancer and warrants further evaluation using in vivo models as well as detailed studies on combinatory mechanisms including cell cycle effects.

\section{Acknowledgements}

The authors thank Steven K. Hanks (Vanderbilt) for providing mouse embryonic fibroblasts and W.K. Song for helpful advice in tubulin polymerization study. This study was supported in part by a grant from the Ministry of Science and Technology (F104AA010007-06A0101-00710), Korea.

\section{References}

1. Bonati A, Rizzoli V and Lunghi P: Arsenic trioxide in hematological malignancies: the new discovery of an ancient drug. Curr Pharm Biotechnol 7: 397-405, 2006.

2. Kim KB, Bedikian AY, Camacho LH, Papadopoulos NE and McCullough C: A phase II trial of arsenic trioxide in patients with metastatic melanoma. Cancer 104: 1687-1692, 2005.

3. Lin $\mathrm{CC}$, Hsu C, Hsu CH, Hsu WL, Cheng AL and Yang CH: Arsenic trioxide in patients with hepatocellular carcinoma: a phase II trial. Invest New Drugs 25: 77-84, 2007.

4. Wang L, Zhou GB, Liu P, Song JH, Liang Y, Yan XJ, Xu F, Wang BS, Mao JH, Shen ZX, Chen SJ and Chen Z: Dissection of mechanisms of Chinese medicinal formula Realgar-Indigo naturalis as an effective treatment for promyelocytic leukemia. Proc Natl Acad Sci USA 105: 4826-4831, 2008.

5. Glienke W, Chow KU, Bauer N and Bergmann L: Downregulation of wt 1 expression in leukemia cell lines as part of apoptotic effect in arsenic treatment using two compounds. Leuk Lymphoma 47: 1629-1638, 2006.

6. Park IC, Park MJ, Woo SH, Lee HC, An S, Gwak HS, Lee SH, Hong SI, Bae IJ, Seo KM and Rhee CH: Tetraarsenic oxide induces apoptosis in $\mathrm{U} 937$ leukemic cells through a reactive oxygen species-dependent pathway. Int J Oncol 23: 943-948, 2003.

7. Phatak P, Dai F, Butler M, Nandakumar MP, Gutierrez PL, Edelman MJ, Hendriks H and Burger AM: KML001 cytotoxic activity is associated with its binding to telomeric sequences and telomere erosion in prostate cancer cells. Clin Cancer Res 14: 4593-4602, 2008

8. Cheung WM, Chu PW and Kwong YL: Effects of arsenic trioxide on the cellular proliferation, apoptosis and differentiation of human neuroblastoma cells. Cancer Lett 8: 122-128, 2007.

9. Kong B, Huang S, Wang W, Ma D, Qu X, Jiang J, Yang X, Zhang Y, Wang B, Cui B and Yang Q: Arsenic trioxide induces apoptosis in cisplatin-sensitive and -resistant ovarian cancer cell lines. Int J Gynecol Cancer 15: 872-877, 2005.

10. Shao QS ,Ye ZY, Ling ZQ and Ke JJ: Cell cycle arrest and apoptotic cell death in cultured human gastric carcinoma cells mediated by arsenic trioxide. World J Gastroenterol 14: 3451-3456, 2005.

11. Yu J, Qian H, Li Y, Wang Y, Zhang X, Liang X, Fu M and Lin C: Therapeutic effect of arsenic trioxide $\left(\mathrm{As}_{2} \mathrm{O}_{3}\right)$ on cervical cancer in vitro and in vivo through apoptosis induction. Cancer Biol Ther 6: 580-586, 2007 
12. Zhang TC, Cao EH, Li JF, Ma W and Qin JF: Induction of apoptosis and inhibition of human gastric cancer MGC-803 cell growth by arsenic trioxide. Eur J Cancer 35: 1258-1263, 1999.

13. Jung BH, Park C, Kim HR and Park MR: Arsenic trioxide induces apoptosis of HL-60 cells via activation of intrinsic caspase protease with mitochondrial Dysfunction. Cancer Res Treat 34: 308-315, 2002.

14. Zhang TD, Chen GQ, Wang ZG, Wang ZY, Chen SJ and Chen Z: Arsenic trioxide, a therapeutic agent for APL. Oncogene 20: 7146-7153, 2001.

15. Miller WH Jr, Schipper HM, Lee JS, Singer J and Waxman S: Mechanisms of action of arsenic trioxide. Cancer Res 62: 3893-3903, 2002.

16. Jin HO, Yoon SI, Seo SK, Lee HC, SH Woo, Yoo DH, Lee SJ, Choe TB, An S, Kwon TJ, Kim JI, Park MJ, Hong SI, Park IC and Rhee CH: Synergistic induction of apoptosis by sulindac and arsenic trioxide in human lung cancer A549 cells via reactive oxygen species-dependent down-regulation of survivin. Biochem Pharmacol 15: 1228-1236, 2006.

17. Chang HS, Bae SM, Kim YW, Kwak SY, Min HJ, Bae IJ, Lee YJ, Shin JC, Kim CK and Ahn WS: Comparison of diarsenic oxide and tetraarsenic oxide on anticancer effects: relation to the apoptosis molecular pathway. Int J Oncol 30: 1129-1135, 2007.

18. Chung WH, Koo HJ and Kuh HJ: Anti-proliferative effect of tetra-arsenic oxide $\left(\mathrm{TetraAs}^{\mathrm{R}}\right)$ in human gastric cancer cells in vitro. J Kor Pharm Sci 37: 305-309, 2007.

19. Park MT, Kang YH, Park IC, Kim CH, Lee YS, Chung HY and Lee SJ: Combination treatment with arsenic trioxide and phytosphingosine enhances apoptotic cell death in arsenic trioxideresistant cancer cells. Mol Cancer Ther 6: 82-92, 2007.

20. Park MJ, Park IC, Bae IJ, Seo KM, Lee SH, Hong SI, Eun CK, Zhang $\mathrm{W}$ and Rhee $\mathrm{CH}$ : Tetraarsenic oxide, a novel orally administrable angiogenesis inhibitor. Int J Oncol 22: 1271-1276, 2003.

21. Lee JW, Park JK, Lee SH, Kim SY, Cho YB and Kuh HJ: Antitumor activity of heptaplatin in combination with 5-fluorouracil or paclitaxel against human head and neck cancer cells in vitro. Anticancer Drugs 17: 377-384, 2006

22. Pan MH, Huang YT, Ho CT, Chang CI, Hsu PC and Sun Pan B: Induction of apoptosis by Meretrix lusoria through reactive oxygen species production, glutathione depletion, and caspase activation in human leukemia cells. Life Sci 79: 1140-1152, 2006

23. Quiñones W, Peña P, Domingo-Sananes M, Cáceres A Michels PA, Avilan L and Concepción JL: Leishmania mexicana: molecular cloning and characterization of enolase. Exp Parasitol 116: $241-251,2007$
24. Chou TC and Talalay P: Quantitative analysis of dose-effect relationships: the combined effect of multiple drugs or enzyme inhibitors. Adv Enzyme Regul 22: 27-55, 1984.

25. Gordon G, Sc D, Michael J and Peckham MD: Exploitable mechanisms in combined radiotherapy-chemotherapy: the concept of additivity. Int J Radiat Oncol Biol 5: 85-91, 1979.

26. Kano Y, Akutsu M, Tsunoda S, Izumi T, Mori K, Fujii H, Yazawa Y, Mano H and Furukawa Y: Schedule-dependent synergism and antagonism between pemetrexed and paclitaxe in human carcinoma cell lines in vitro. Cancer Chemother Pharmacol 54: 505-513, 2004

27. Jiang $\mathrm{XH}$, Wong BC, Yuen ST, Jiang SH, Cho $\mathrm{CH}$, Lai KC, Lin MC, Kung HF and Lam SK: Arsenic trioxide induces apoptosis in human gastric cancer cells through up-regulation of p53 and activation of caspase-3. Int J Cancer 91: 173-179, 2001 .

28. Karlsson J, Øra I, Pörn-Ares I and Påhlman S: Arsenic trioxideinduced death of neuroblastoma cells involves activation of Bax and does not require p53. Clin Cancer Res 10: 3179-3188, 2004.

29. Górka M, Daniewski WM, Gajkowska B, Lusakowska E, Godlewski MM and Motyl T: Autophagy is the dominant type of programmed cell death in breast cancer MCF-7 cells exposed to AGS 115 and EFDAC, new sesquiterpene analogs of paclitaxel. Anticancer Drugs 16: 777-788, 2005.

30. Kanzawa T, Kondo Y, Ito H, Kondo S and Germano I: Induction of autophagic cell death in malignant glioma cells by arsenic trioxide. Cancer Res 63: 2103-2108, 2003.

31. Fujie Y, Yamamoto H, Ngan CY, Takagi A, Hayashi T, Suzuki R, Ezumi K, Takemasa I, Ikeda M, Sekimoto M, Matsuura N and Monden M: Oxaliplatin, a potent inhibitor of survivin, enhances paclitaxel-induced apoptosis and mitotic catastrophe in colon cancer cells. Jpn J Clin Oncol 35: 453-463, 2005.

32. Gu J, Yamamoto H, Lu X, Ngan CY, Tsujino T, Konishi K, Takemasa I, Ikeda M, Nagata H, Hashimoto S, Matsuzaki T, Sekimoto M, Takagi A and Monden M: Low-dose oxaliplatin enhances the antitumor efficacy of paclitaxel in human gastric cancer cell lines. Digestion 74: 19-27, 2006.

33. Peyrot V, Briand C, Crevat A, Braguer D, Chauvet-Monges AM and Sari JC: Action of hydrolyzed cisplatin and some analogs on microtubule protein polymerization in vitro. Cancer Treat Rep 67: 641-646, 1983.

34. Carré M, Carles G, André N, Douillard S, Ciccolini J, Briand C and Braguer D: Involvement of microtubules and mitochondria in the antagonism of arsenic trioxide on paclitaxel-induced apoptosis. Biochem Pharmacol 63: 1831-1842, 2002. 